Article

\title{
Airline Chief Executive Officer and Corporate Social Responsibility
}

\author{
Luo Jing ${ }^{1}$ and Joonho Moon ${ }^{2, *(1)}$ \\ 1 Department of Tourism Management, Dong-A University, 225 Gudeok-ro, Seo-gu, Busan 49236, Korea; \\ ljqp_tvxq@naver.com \\ 2 Department of Tourism Administration, Kangwon National University, Kangwon University Rd., \\ Hyoja-dong, Chooncheon 24341, Korea \\ * Correspondence: joonhomoon0412@gmail.com
}

check for

updates

Citation: Jing, L.; Moon, J. Airline Chief Executive Officer and

Corporate Social Responsibility.

Sustainability 2021, 13, 8599.

https://doi.org/10.3390/su13158599

Academic Editor: Andrea Pérez

Received: 15 July 2021

Accepted: 29 July 2021

Published: 2 August 2021

Publisher's Note: MDPI stays neutral with regard to jurisdictional claims in published maps and institutional affiliations.

Copyright: (c) 2021 by the authors. Licensee MDPI, Basel, Switzerland. This article is an open access article distributed under the terms and conditions of the Creative Commons Attribution (CC BY) license (https:// creativecommons.org/licenses/by/ $4.0 /)$.

\begin{abstract}
The aim of this research is to explore the determinants of airline CSR. Stakeholder theory is the theoretical underpinning. Chief executive officers (CEOs) are the research target, which is theoretically underpinned by upper echelon theory. For data collection, this study used data from COMPUSTAT, EXECUCOMP, KLD MSCI, LinkedIn, and the Bureau of Economic Analysis. Standard industry classification code 4512 was employed to obtain information on airline companies. Moreover, the number of observations was 154, the number of firms was 15, and the study period was 1999-2016. CSR domains include employment, the environment, and the product. The explanatory attributes are the CEO's age, tenure, education, share ownership, stock option, and duality. Ordinary least squares and feasible generalized least squares regression analyses were executed for hypothesis testing. Regarding the results, employment CSR was positively affected by CEO age. This study found an inverted U-shaped relationship between CEO tenure and environmental CSR. Environmental CSR was also negatively influenced by stock options. Product CSR was positively associated with CEO age, whereas it was negatively associated with CEO duality.
\end{abstract}

Keywords: CSR; airline; chief executive officer; age; tenure; stock option; duality

\section{Introduction}

Corporate social responsibility (CSR) has become a critical element for the achievement of business sustainability [1-3]; CSR can also be applied to the airline business because numerous stakeholders (e.g., employees, customers from diverse geographical regions, and suppliers) are engaged in this business, and they have become more integral to the survival of organization over time [3-5]. Given the power growth of stakeholders, CSR has received a great deal of attention, as it is needed for companies to achieve business sustainability because the careless treating of shareholders may have enormous negative effects (e.g., firm value destruction and poor reputation) on companies [6,7]. For example, Varma [7] documented that a compulsory passenger removal scandal involving United Airlines and Delta, two major American full-service carriers, caused the stock price to fall and led to a decline in market and brand reputation. The essence of stakeholders has been addressed in stakeholder theory, and previous research has indicated that the influential stakeholders of airlines are employees, customers, and the environment because airline businesses are labor-intensive and service-oriented, which leads airline businesses to make customer service more critical [5-7]. Eco-friendly management builds a friendly reputation that encourages customers to make purchases [6-11]. This study thus chooses the employee, customer, and environment as the main domains of CSR.

Upper echelons theory is the theoretical underpinning for the determination of CSR and emphasizes the role of top managers in determining organizational fate and strategic execution [12]. Among top managers, numerous studies have performed research by 
considering chief executive officers (CEOs) who are powerful individuals in organizations [13-18], as it is inferred that it is valuable to scrutinize CEOs. Indeed, Herb Kelleher, a star CEO of Southwest Airlines, may contribute to the airline business success. It indicates that the influence of CEO in airlines is valuable topic to research. This study thus investigates CEOs as the research target because they are responsible for strategic decision making and outcomes in organizations. After browsing the extant literature on upper echelons theory, which recommends the use of observable characteristics to anticipate the strategic decisions of top managers, this study selects CEOs' age, tenure, education, share value, stock option value, and duality [12-26].

However, empirical works exploring the link between stakeholder theory and upper echelons theory have been sparse in the airline business domain. Even though Lee and Moon [27] explored the effect of CEO attributes on strategic risk-taking in the airline domain, the main elements are limited to three attributes (e.g., age, tenure, and education); the explanatory power of CEOs for CSR has rarely been researched. Such a research gap leads this study to examine the association of the above two theories in the airline context, which can shed light on the airline business and CSR literature. In summary, the aim of this study is to ensure the accountability of upper echelons attributes for the CSR management of airlines. The domains of CSR include employees, products, and the environment. By examining the effect of CEO-related elements, this study attempts to produce information on CEO recruitment for shareholders and directions for airline CSR execution for competitors in the airline domain. Hence, the purpose of this research is to inspect the determinants of airline CSR execution using CEOs' observable elements. Three CSR domains (e.g., employee, environmental, and consumer) are adopted, and six variables (e.g., age, tenure, education, share ownership, stock option, and duality) are chosen.

\section{Literature Review and Hypothesis Development}

\subsection{Stakeholder Theory and CSR}

The term 'stakeholders' refer to either individuals or groups who are linked with business administration $[28,29]$. Stakeholder theory states that businesses achieve sustainability by establishing favorable relationships with stakeholders and shareholders because stakeholders have become more powerful $[8,30,31]$. CSR is a representative channel through which to engage in friendlier relations with stakeholders by fulfilling their demands; such an amicable relationship plays a critical role by maximizing social benefits as virtuous cycle [32-34]. Regarding airline stakeholders, Inoue and Lee [9] found that airlines that meet employee and consumer demands contribute to market value creation because employees create the product and customers consume it. Cheng and Shen [6] documented that airlines that have poorly performing stakeholder management end up losing their customers, which threatens business survival. Kuo, Kremer, Phuong, and Hsu [35] noted that the main goals of airline CSR are better consumer assessment and employee perception, which are closely related to the business sales growth. Another area of stakeholder management is the environmental domain. Theodoulidis, Diaz, Crotto, and Rancati [36] unveiled that environmental CSR is an auxiliary attribute to enhance performance in the domain of airline business. Additionally, Hwang and Choi [10] reported that environmental CSR builds a positive image of airlines, while Kim, Lee, and Roh [11] demonstrated that environmental CSR is essential for building airline customer loyalty because environmental concerns have become more critical over time. A literature review has indicated that employee, environmental, and customer concerns are essential areas in the context of airline business for the accomplishment of sustainability.

The extant literature argues that CSR functions as a type of insurance through the building of pleasing relationships with stakeholders, and stakeholders become the patrons of the business [37-40]. Scholars have also stated that CSR is a relatively less risky resource allotment than other strategic executions (e.g., internationalization and R\&D investment); furthermore, the profitability of CSR is modest [40-43]. Moreover, previous research has indicated that CSR may not be an attractive project; however, CSR-related corporate 
scandals (e.g., the Volkswagen emissions scandal, Nike child labor issues in third-world countries, and United Airlines ethnic discrimination) have caused serious losses (e.g., in terms of stock value, reputation, brand value, and market share) for businesses [43-46]. Hence, CSR can become relatively less complicated and profitable but not negligible.

\subsection{Upper Echelons Theory and Chief Executive Officers (CEOs)}

The theoretical foundation of the current work is upper echelons theory, according to which top managers play a pivotal role in the fate of organizations because they are authorized to make decisions [12]. Top managers' views are limited, and they make decisions based on their value and cognition [47]. A representative example of a top manager is a CEO; numerous studies have adopted CEOs to determine organizational strategic execution (e.g., debt financing, CSR, internationalization, and R\&D) with upper echelons theory as the theoretical foundation $[14,15,17,18]$.

Considering the link between CEOs and CSR, a vast body of literature has exposed the role of CEOs in CSR execution [47-50]. Moreover, prior studies have examined the link between CSR and CEO characteristics in various industries. Specifically, Kim, Lee, and Kang [51] explored the impact of CEO characteristics on restaurant CSR execution. Javeed and Lefen [52] researched the link between CEO attributes and CSR implementation in the manufacturing context. Toppinen, Hänninen, and Lähtinen [53] found a significant impact of CEO-related elements on resource allocation to CSR by focusing on companies in the paper business. Similarly, Jizi, Salama, Dixon, and Stratling [54] suggested an association between banking business CEO characteristics and CSR execution. Jamali, Hallal, and Abdallah [55] unveiled a significant connection between CEOs' observable elements and CSR implementation in the healthcare domain. In the case of airlines, Davila and Venkatachalam [56] examined the effect of CEO compensation, while Lee and Moon [27] used physical age, tenure, and education to determine the strategic risk taking of airlines. It suggests that the link between upper echelon attributes and CSR execution of airlines have scantly examined by scholars. Regarding the literature review, it can be inferred that scholars have examined the relationship between upper echelons attributes and CSR in various industries, although this relationship has rarely been examined in the airline context.

\subsection{Hypotheses Development}

Upper echelons theory proposes observable attributes (e.g., age, tenure, education, and compensation package) because it is difficult to measure the psychological attributes of top managers [12]. The first area is physical age. Serfling [13] demonstrated that older CEOs are more conservative because their mental stamina is weaker than that of younger CEOs. Yim [49] empirically revealed that older CEOs took less acquisition, which is regarded as a sort of strategic risk-taking. Similarly, Andreou, Louca, and Petrou [14] presented that younger CEOs' management caused more stock price variation, indicating that older CEOs administer organization as more stable manners. This study thus proposes the following hypothesis:

\section{Hypothesis 1. CEO age positively affects airline CSR execution.}

Tenure, the working period of individuals in an organization, is another crucial element in the top management domain [12]. The extant literature has illustrated that CEOs are eager to begin their tasks when they first join a company for the purpose of displaying their capabilities; however, their fatigue leads their organizations to become less assiduous once they reach their goal [57-59]. To be specific, Luo, Kanuri, and Andrew [16] exhibited that there was an inverted-U shape relationship between CEO's tenure and CSR execution such as employee management. Chen [15] and Hsu, Chen, and Ho [60] uncovered that CEO tenure exerted a curve linear (inverted-U shape) effect on R\&D investment of business. Thus, the following research hypothesis is proposed: 
Hypothesis 2. CEO tenure presents an inverted U-shaped association with airline CSR execution.

The next area is education. Scholars have claimed that CEO education is an important factor in CSR according to Hambrick and Mason [12]. In fact, prior studies have found that more educated CEOs, compared to less educated CEOs, take more strategic risk because education builds a higher level of confidence for resource allocation because the education enabled them to become more confident to cope with more complex situations $[27,50,56]$. In detail, Farag and Mallin [61] found that CEOs that possess a postgraduate degree took more strategic risk than CEOs that possess a non-postgraduate degree by exploring Chinese initial public offering. Moreover, Li and Tang [18] noted that CEOs' education with higher level of academic education are more likely to take risk in their strategic implementation. Considering prior studies, the third hypothesis is proposed as follows:

Hypothesis 3. CEO education negatively affects airline CSR execution.

Previous research has noted that CEO powers can be estimated based on share value because shares grant voting rights; CEOs possessing more shares pursue more profitable projects for their wealth maximization [62,63]. Zhu and Chen [21] disclosed that powerful CEOs possessing more shares invested more in riskier projects by employing Fortune 500 companies. Sheikh [22] demonstrated that CEO stock values caused riskier business conditions using publicly traded firms on the American stock market. Altunbaş, Thornton, and Uymaz [23] also reported that CEO share ownership leads businesses to choose more profitable projects by examining American bank industry CEOs. Therefore, this study presents the fourth hypothesis as follows:

Hypothesis 4. CEO share value negatively affects airline CSR execution.

Scholars have noted that stock options are a crucial attribute for the resource allotment of top managers because stock options do not charge penalties, which leads top managers to more comfortably take risks $[12,25,26]$. Rajgopal and Shevlin [25] found that CEO stock options positively affected business risk-taking. Lee, Kim, and Moon [64] documented that restaurant internationalization, riskier strategic execution, is positively influenced by CEO stock options. Additionally, Hou, Lovett, and Rasheed [65] researched S\&P 1500 firms; the results suggested that CEO stock options are positively associated with strategic risk-taking. By integrating the literature review, this study proposes the following research hypothesis:

Hypothesis 5. CEO stock option value negatively affects airline CSR execution.

CEO duality, the attainment of a position as both a CEO and chairperson on the board of directors, presents the power of CEOs [66]. According to Muttakin, Kahn, and Mihret [67], CEOs pursue more profitable projects because they are interested in maintaining power and gaining more wealth than they are caring for stakeholders (less profitable). Lewellyn and Muller-Kahle [68] showed that CEO duality caused more CEO risk-taking. Additionally, Ozdemir, Erkmen, and Binesh [69] unveiled that CEO duality positively impacted on the risk-taking of tourism-related business such as hotels and airlines. This research thus proposes the following hypothesis:

Hypothesis 6. CEO duality negatively affects airline CSR execution.

\section{Method}

\subsection{Data and Variable Description}

This study collected data using multiple information sources. COMPUSTAT was the source of financial information, while EXECUCOMP was chosen to attain CEO information 
(e.g., compensation, status, and position) using standard industry classification code 4512. Additional airline company information was derived from Annual 10K. Moreover, this research used LinkedIn (http:/ / www.linkedin.com, accessed on 15 December 2020) to obtain information on CEO education level. Macroeconomic information, such as oil prices and gross domestic product, was attained using the Bureau of Economic Analysis (https:/ / www.bea.gov, accessed on 15 December 2020). This study also acquired CSR information by means of MSCI KLD. Panel data, consisting of multiple firms and years, were employed for data analysis. The number of firms was 15, and the study period was 1999-2016 given the availability of MSCI KLD. The number of valid observations was 154 for the data analysis, which suggests that the data are unbalanced panel data because all firms did not present the financial information during the entire study period. Table 1 describes the list of airline businesses utilized in this research.

Table 1. List of companies.

\section{Company Name}

American Airlines Group Inc.

Alaska Air Group Inc.

US Airway Group Inc.

Delta Airlines Inc.

Northwest Airlines Corp.

Southwest Airlines

United Continental Holdings Inc.

SkyWest Inc.

Mesa Air Group Inc. Flyi Inc.

Frontier Airlines Holdings

AirTran Holdings Inc.

Midwest Air Group Inc.

JetBlue Airways Corp.

Allegiant Travel Co.

Table 2 presents the measurements of the variables. EMP, ENV, and PRO were the dependent variables in this research, and the independent variables were AGE, TEN, EDU, SHO, SHA, and DUA. This study also used SIZE, DEBT, GDP, OIL, and LCC as control variables. In sum, this study used three dependent variables, six independent variables, and five control variables.

Table 2. Variable illustration.

\begin{tabular}{|c|c|c|}
\hline Variable & Description & Measure \\
\hline EMP & Employee CSR & Sum of strength—sum of weakness in employee CSR \\
\hline ENV & Environmental CSR & Sum of strength-sum of weakness in environmental CSR \\
\hline $\mathrm{PRO}$ & Product CSR & Sum of strength—sum of weakness in product CSR \\
\hline AGE & CEO's age & Physical age of CEO \\
\hline TEN & CEO's tenure & Working period as CEO (unit $=$ year) \\
\hline EDU & CEO's education & CEO academic terminal degree ( $0=$ bachelor, $1=$ graduate school $)$ \\
\hline $\mathrm{SHO}$ & CEO's value of share & Value of share possessed by CEO (thousand: US dollars) \\
\hline STO & CEO's value of stock option & Value of stock option possessed by CEO (thousand: US dollars) \\
\hline DUA & CEO duality & $0=$ non-duality, $1=$ duality \\
\hline SIZE & Firm size & Total assets (million: US dollars) \\
\hline DEBT & Financial leverage & Total debt/total \\
\hline GDP & Gross domestic product & US annual gross domestic product (trillion: US dollars) \\
\hline OIL & Oil price & Oil price per barrel (US dollars) \\
\hline LCC & Low-cost carrier & $0=$ non-low-cost carrier, $1=$ low-cost carrier \\
\hline
\end{tabular}

\subsection{Data Analysis}

This study initially computed the mean value, standard deviation, minimum, and maximum to obtain descriptive attribute information. Then, this study implemented Pearson correlation matrix analysis to inspect the variable characteristics within two attributes. 
Next, ordinary least squares regression analysis was executed to test the proposed hypotheses. Ordinary least squares regression is the baseline estimation instrument in econometric model. We also included GDP and OIL were the variables chosen to capture the year effect in the panel data; they function to minimize omitted variable bias in parameter estimation because the panel data contains multiple year information [70,71]. Moreover, this study executed feasible generalized least squares regression analysis to minimize the bias caused by heteroskedasticity and autocorrelation in panel data estimation [72]. Confirming the consistency in the results of two regression regarding direction and significance, the robustness of the results of regression analyses was ensured. All things considered, the regression equations of this study are as follows:

$$
\begin{aligned}
& E M P_{i t}=\beta_{0}+\beta_{1} A G E_{i t}+\beta_{2} T E N_{i t}+\beta_{3} T E N^{2}{ }_{i t}+\beta_{4} E D U_{i t}+\beta_{5} S H O_{i t}+\beta_{6} S T O_{i t}+\beta_{7} \\
& D U A_{i t}+\beta_{8} S I Z E_{i t}+\beta_{9} D E B T_{i t}+\beta_{10} G D P_{i t}+\beta_{11} O I L_{i t}+\beta_{12} L C C_{i t}+\varepsilon_{i t} \\
& E N V_{i t}=\beta_{0}+\beta_{1} A G E_{i t}+\beta_{2} T E N_{i t}+\beta_{3} T E N^{2} i t+\beta_{4} E D U_{i t}+\beta_{5} S H O_{i t}+\beta_{6} S T O_{i t}+\beta_{7} D U A_{i t} \\
& +\beta_{8} \operatorname{SIZE}_{i t}+\beta_{9} D E B T_{i t}+\beta_{10} G D P_{i t}+\beta_{11} \text { OIL }_{i t}+\beta_{12} L C C_{i t}+\varepsilon_{i t} \\
& P R O_{i t}=\beta_{0}+\beta_{1} A G E_{i t}+\beta_{2} T E N_{i t}+\beta_{3} T E N^{2} i t+\beta_{4} E D U_{i t}+\beta_{5} S H O_{i t}+\beta_{6} S T O_{i t}+\beta_{7} D U A_{i t} \\
& +\beta_{8} \text { SIZE }_{i t}+\beta_{9} D E B T_{i t}+\beta_{10} G D P_{i t}+\beta_{11} \text { OIL }_{i t}+\beta_{12} L_{C C} C_{i t}+\varepsilon_{i t}
\end{aligned}
$$

where $i$ is the $i_{\text {th }}$ firm, $t$ is $t_{\text {th }}$ year, and $\varepsilon$ is the residual.

\section{Results}

\subsection{Descriptive Statistics and Correlation Matrix}

Table 3 presents the descriptive statistics. The mean values of EMP, ENV, and PRO are $0.13,0.19$, and -0.41 , respectively. Table 3 also presents CEO information of the airline industry (AGE (mean $=53.39, \mathrm{SD}=5.95)$, TEN (mean $=7.77, \mathrm{SD}=9.41)$, EDU (mean = 0.59, $\mathrm{SD}=0.49)$, SHO $($ mean $=1126.45, \mathrm{SD}=1737.11)$, $\mathrm{STO}($ mean $=347.83, \mathrm{SD}=1080.25)$, and DUA (mean $=0.62, \mathrm{SD}=0.48)$ ). Moreover, the mean value of SIZE is 13,924.37, and its standard deviation is $14,785.93$. For DEBT, the mean is 0.79 with a standard deviation of 0.24. Additionally, Table 3 depicts the descriptive information of GDP (mean $=13.73$, $\mathrm{SD}=2.58)$, OIL $($ mean $=60.46, \mathrm{SD}=31.84)$, and $\mathrm{LCC}($ mean $=0.24, \mathrm{SD}=0.42)$.

Table 3. Descriptive statistics.

\begin{tabular}{ccccc}
\hline Variable & Mean & SD & Minimum & Maximum \\
\hline EMP & 0.13 & 1.37 & -4 & 4 \\
ENV & 0.19 & 0.53 & -1 & 2 \\
PRO & -0.41 & 0.85 & -3 & 1 \\
AGE & 53.39 & 5.95 & 37 & 67 \\
TEN & 7.77 & 9.41 & 1 & 1 \\
EDU & 0.59 & 0.49 & 0 & $10,783.28$ \\
SHO & 1126.45 & 1737.11 & 0 & $10,377.85$ \\
STO & 347.83 & 1080.25 & 0 & 1 \\
DUA & 0.62 & 0.48 & 0 & $54,121.00$ \\
SIZE & $13,924.37$ & $14,785.93$ & 305.72 & 2.32 \\
DEBT & 0.79 & 0.24 & 0.28 & 18.71 \\
GDP & 13.73 & 2.58 & 9.63 & 110.63 \\
OIL & 60.46 & 31.84 & 18.6 & 1 \\
LCC & 0.24 & 0.42 & 0 & \\
\hline
\end{tabular}

Note: SD stands for standard deviation.

Table 4 is a correlation matrix. EMP is positively correlated with PRO $(\mathrm{r}=0.42$, $p<0.05)$, AGE $(\mathrm{r}=0.24, p<0.05)$, and LCC $(\mathrm{r}=0.46)$. ENV is positively correlated with SIZE $(r=0.23, p<0.05)$ and GDP $(r=0.32, p<0.05)$. PRO is positively correlated with AGE $(r=0.15, p<0.05)$ and LCC $(r=0.42, p<0.05)$, while it is negatively correlated with DUA $(r=-0.33, p<0.05)$, SIZE $(r=-0.32, p<0.05)$, and DEBT $(r=-0.29, p<0.05)$. AGE shows a positive correlation with TEN $(\mathrm{r}=0.39, p<0.05)$ and DUA $(\mathrm{r}=0.28, p<0.05)$; 
TEN is positively correlated with EDU $(r=0.23, p<0.05)$ and SHO $(r=0.20, p<0.05)$. STO presents a positive correlation with SIZE $(r=0.31, p<0.05)$. Additionally, SIZE is positively correlated with DEBT $(\mathrm{r}=0.42, p<0.05)$ but negatively correlated with LCC $(\mathrm{r}=-0.21, p<0.05)$. Finally, GDP is positively correlated with OIL $(\mathrm{r}=0.77, p<0.05)$.

Table 4. Correlation matrix.

\begin{tabular}{|c|c|c|c|c|c|c|c|c|c|c|c|c|c|}
\hline Variable & 1 & 2 & 3 & 4 & 5 & 6 & 7 & 8 & 9 & 10 & 11 & 12 & 13 \\
\hline 1. EMP & 1 & & & & & & & & & & & & \\
\hline 2. ENV & 0.02 & 1 & & & & & & & & & & & \\
\hline 3. PRO & $0.42 *$ & $-0.16^{*}$ & 1 & & & & & & & & & & \\
\hline 4. AGE & $0.24 *$ & 0.04 & $0.15 *$ & 1 & & & & & & & & & \\
\hline 5. TEN & 0.04 & -0.08 & 0.11 & $0.39 *$ & 1 & & & & & & & & \\
\hline 6. EDU & -0.06 & -0.05 & -0.08 & 0.13 & $23 *$ & 1 & & & & & & & \\
\hline 7. SHO & 0.07 & -0.04 & 0.12 & 0.01 & $20 *$ & 0.03 & 1 & & & & & & \\
\hline 8. STO & -0.05 & 0.01 & -0.1 & 0.08 & -0.02 & -0.01 & -0.04 & 1 & & & & & \\
\hline 9. DUA & -0.01 & 0.09 & -0.33 * & $0.28 *$ & $0.32 *$ & 0.02 & -0.06 & -0.04 & 1 & & & & \\
\hline 10. SIZE & -0.06 & $0.23 *$ & $-0.32 *$ & 0.1 & $\begin{array}{c}-0.28 \\
*\end{array}$ & 0.04 & $-0.18 *$ & $0.31 *$ & -0.08 & 1 & & & \\
\hline 11. DEBT & $-0.42 *$ & 0.13 & $-0.29^{*}$ & -0.14 & $\underset{*}{-0.31}$ & -0.1 & -0.20 * & 0.06 & -0.02 & 0.42 * & 1 & & \\
\hline 12. GDP & 0.11 & $0.32 *$ & -0.01 & $0.26^{*}$ & 0.13 & 0.15 & 0.06 & 0.20 * & 0.11 & 0.33 * & 0.05 & 1 & \\
\hline 13. OIL & 0.07 & $0.40 *$ & 0.01 & $0.19 *$ & 0.13 & 0.14 & 0.06 & 0.14 & 0.08 & $0.21 *$ & 0.04 & $0.77^{*}$ & 1 \\
\hline 14. LCC & $0.46^{*}$ & 0.01 & $0.42 *$ & -0.24 & -0.14 & $-0.41 *$ & $0.16^{*}$ & -0.13 & -0.39 * & $\begin{array}{c}-0.21 \\
*\end{array}$ & $-0.27 *$ & -0.01 & 0.01 \\
\hline
\end{tabular}

Note: ${ }^{*} p<0.05$

\subsection{Results of Hypothesis Testing}

Table 5 describes the results of ordinary least squares regression. Three models are statistically significant in terms of their F-values $(p<0.05)$. In model 1 , AGE exerts a positive effect on EMP ( $\beta=0.077, p<0.05)$; DEBT $(\beta=-1.652, p<0.05)$ and LCC $(\beta=1.882, p<0.05)$ appear to be significant attributes to account for EMP. Model 2 shows that TEN squares $(\beta=-0.001, p<0.05)$ and STO $(\beta=-0.001, p<0.05)$ are significant in the negative direction, while OIL is significant in the positive direction $(\beta=0.059, p<0.05)$. Regarding model 3, PRO is positively influenced by AGE $(\beta=0.047, p<0.05)$. However, PRO is negatively impacted by DUA $(\beta=-0.638, p<0.05)$ and SIZE $(\beta=-0.001, p<0.05)$. Table 6 shows the results of the feasible generalized least squares method. The results appear similar to those in Table 5 in terms of direction and significance. However, TEN squares and STO are not significant in accounting for ENV in Table 6. In sum, SHO and EDU are nonsignificant to account for CSR, while AGE, TEN squares, STO, and DUA are significant determinants of CSR.

Table 5. Results of regression analysis—ordinary least square.

\begin{tabular}{cccc}
\hline Variable & $\begin{array}{c}\text { Model 1 (EMP) } \\
\beta \text { (T-Stat) }\end{array}$ & $\begin{array}{c}\text { Model 2 (ENV) } \\
\beta \text { (T-Stat) }\end{array}$ & $\begin{array}{c}\text { Model 3 (PRO) } \\
\beta \text { (T-Stat) }\end{array}$ \\
\hline Intercept & $-3.881(-3.08)^{* *}$ & $-0.073(-0.17)$ & $-2.501(-3.55)^{* *}$ \\
AGE & $0.077(3.84)^{* *}$ & $-0.005(-0.80)$ & $0.047(4.92)^{* *}$ \\
TEN & $-0.007(-0.25)$ & $0.016(1.43)$ & $0.010(0.56)$ \\
TEN2 & $-0.001(-0.39)$ & $-0.001(-2.00)^{*}$ & $-0.001(-0.42)$ \\
EDU & $0.338(1.64)$ & $-0.037(-0.37)$ & $-0.010(-0.08)$ \\
SHO & $-0.001(-0.86)$ & $-0.001(-1.25)$ & $-0.001(-1.02)$ \\
STO & $-0.001(-0.60)$ & $-0.001(-2.06)^{*}$ & $-0.001(-0.30)$ \\
DUA & $0.379(1.81)$ & $0.105(1.19)$ & $-0.638(-4.44)^{* *}$ \\
SIZE & $0.001(1.75)$ & $0.001(1.97)$ & $-0.001(-3.62)^{* *}$ \\
DEBT & $-1.652(-2.22)^{*}$ & $0.095(0.46)$ & $-0.155(-0.45)$ \\
\hline
\end{tabular}


Table 5. Cont.

\begin{tabular}{cccc}
\hline Variable & Model 1 (EMP) & Model 2 (ENV) & Model 3 (PRO) \\
$\beta$ (T-Stat) & $\beta$ (T-Stat) & $0.013(0.33)$ \\
GDP & $0.015(0.44)$ & $0.001(0.04)$ & $0.001(0.19)$ \\
OIL & $-0.001(-0.28)$ & $0.006(2.99)^{* *}$ & $0.580(3.58)^{* *}$ \\
LCC & $1.882(7.22)^{* *}$ & $0.059(0.59)$ & $10.07^{* *}$ \\
F-value & $12.65^{* *}$ & $3.46^{* *}$ & 0.4174 \\
R2 & 0.4614 & 0.2496 & \\
\hline
\end{tabular}

Note: ${ }^{*} p<0.05,{ }^{* *} p<0.01$, dependent variable: EMP (model 1), ENV (model 2), and PRO (model 3).

Table 6. Results of regression analysis-feasible generalized least square.

\begin{tabular}{cccc}
\hline Variable & $\begin{array}{c}\text { Model 4 (EMP) } \\
\beta \text { (Wald) }\end{array}$ & $\begin{array}{c}\text { Model 5 (ENV) } \\
\beta \text { (Wald) }\end{array}$ & $\begin{array}{c}\text { Model 6 (PRO) } \\
\beta \text { (Wald) }\end{array}$ \\
\hline Intercept & $-3.881(-3.62)^{* *}$ & $-0.073(-0.15)$ & $-2.501(-3.59)^{* *}$ \\
AGE & $0.077(4.72)^{* *}$ & $-0.005(-0.70)$ & $0.047(4.48)^{* *}$ \\
TEN & $-0.007(-0.28)$ & $0.016(1.32)$ & $0.010(0.62)$ \\
TEN2 & $-0.001(-0.40)$ & $-0.001(-1.89)$ & $-0.001(-0.48)$ \\
EDU & $0.338(1.66)$ & $-0.037(-0.40)$ & $-0.010(-0.08)$ \\
SHO & $-0.001(-0.65)$ & $-0.001(-0.87)$ & $-0.001(-0.69)$ \\
STO & $-0.001(-0.34)$ & $-0.001(-1.44)$ & $-0.001(-0.22)$ \\
DUA & $0.379(1.82)$ & $0.105(1.11)$ & $-0.638(-4.71)^{* *}$ \\
SIZE & $0.001(1.78)$ & $0.001(1.96)^{*}$ & $-0.001(-3.96)^{* *}$ \\
DEBT & $-1.652(-3.93)^{* *}$ & $0.095(0.50)$ & $-0.155(-0.57)$ \\
GDP & $0.015(0.30)$ & $0.001(0.04)$ & $0.013(0.39)$ \\
OIL & $-0.001(-0.24)$ & $0.006(3.69)^{* *}$ & $0.001(0.22)$ \\
LCC & $1.882(7.02)^{* *}$ & $0.059(0.49)$ & $0.580(3.33)^{* *}$ \\
Wald $\chi^{2}$ & $131.92^{*}$ & $51.24^{*}$ & $110.32^{*}$ \\
\hline
\end{tabular}

Note: ${ }^{*} p<0.05,{ }^{* *} p<0.01$, dependent variable: EMP (model 4), ENV (model 5), and PRO (model 6).

\section{Discussion and Conclusions}

This study examined the effect of CEO attributes on the CSR decisions of airlines. This study argued that airline CSR is less profitable and complex strategic execution. Based on the literature review, this study chose employment, the environment, and consumers as the CSR domains for airline business. Publicly traded airlines were the study subjects. The results are summarized in Table 7. In detail, age for H1 appeared as a significant determinant of employee CSR and product CSR, which supported the findings of Yim [16] and Serfling [51]. Regarding H2, tenure was identified as a significant attribute to account for environmental CSR. The results validated the results of Chen [53] and Hsu, Chen, and Ho [55] in the area of airline management. Considering education H3 and share ownership $\mathrm{H} 4$, both elements appeared as nonsignificant determinants of airline CSR. In terms of stock option (H5), the variable significantly affected only environmental CSR. The results similarly appeared with the findings of Sanders and Hambrick [13] and Rajgopal and Shevlin [64]. Lastly, duality for H6 worked as a significant antecedent of only product CSR. The finding externally validated the results of Lewellyn and MullerKahle [68]. The results indicate that older CEOs execute more employee CSR and product CSR than do younger CEOs. It can be inferred that older CEOs pursue safer strategic execution considering both employee and product CSR. Additionally, this study found a curved linear effect of tenure on CEOs' dedication to environmental CSR execution. That is, CEOs tend to become skeptical as they become accustomed to their position, although they are eager to engage in environmental CSR when they begin serving as top managers. This study also unveiled that stock options led CEOs to act with less CSR. It indicates that CEOs are likely to pursue more profitable and riskier investments than CSR if they possess more stock options because they are not responsible for poor business outcomes. Furthermore, the results imply that CEO duality brings about less resource dedication toward product CSR because more powerful CEOs are likely to look for more profitable projects rather 
than CSR projects, which are relatively less profitable. Regarding the control variables, the findings indicate that low-cost carriers implement more employee CSR and product CSR. Namely, low-cost carriers value their employees and customers more than full-service carriers. Plus, the results suggest that more debt financing by airlines is associated with less employee CSR. However, CEO education and share ownership appear as non-significant attributes to account for the CSR execution of airlines.

Table 7. Summary of the results.

\begin{tabular}{ccccc}
\hline Hypothesis Variable & Direction & Employee CSR & $\begin{array}{c}\text { Results } \\
\text { Environmental CSR }\end{array}$ & Product CSR \\
\hline Hypothesis 1: Age & $(+)$ & Supported & Not supported & Supported \\
Hypothesis 2: Tenure & $(\cap)$ & Not supported & Supported & Not supported \\
Hypothesis 3: Education & $(-)$ & Not supported & Not supported & Not supported \\
Hypothesis 4: Share ownership & $(-)$ & Not supported & Not supported & Not supported \\
Hypothesis 5: Stock option & $(-)$ & Not supported & Supported & Not supported \\
Hypothesis 6: Duality & $(-)$ & Not supported & Not supported & Supported \\
\hline
\end{tabular}

This study contributes to the literature by demonstrating the explanatory power of the attributes (e.g., age, tenure, education, share ownership, stock option, and duality) derived from upper echelons theory in terms of airline CSR implementations (e.g., employee, customer, and environmental CSR) which are attained by the assertion of stakeholder theory. Previous studies have also documented that CSR executions are likely to appear in different forms depending on the industry because stakeholder dynamics vary across business sectors [73-79]. Such variation implies that CEOs' strategic choices are likely to be uniquely in the area of airline management. Scholars have thus demonstrated the explanatory power of upper echelons theory for CSR in diverse management sectors such as service, manufacturing, and financial management [44-48]; however, insufficient works to ensure the link between top management and CSR decisions have been executed in the airline domain. To narrow this gap, this study adopted upper echelons theory as a theoretical underpinning to determine CSR, which can be considered the theoretical contribution of this research. Moreover, this study scrutinized CSR regarding three domains, which leads this research to gain more delicate implications for strategic decision making. Additionally, this research expanded the airline top management literature by ensuring more diverse observable attributes as compared to Lee and Moon [27]. Next, the results of this study are externally validated by prior studies. For example, the finding of Serfling [13] is aligned with the current research in terms of the significance of CEO age. Additionally, the results also appear similar to the findings of Luo et al. [16] with regard to the inverted U-shaped effect of CEO tenure on airline CSR. Regarding stock options, the results of this research support the effect of stock options as claimed by Sanders and Hambrick [26]. Finally, the findings of Harper and Sun [73] are externally validated by the significance of CEO duality.

This study has practical implications. First, the results of this study can be used for CEO recruitment. For instance, if shareholders desire to strengthen employee welfare in airline companies, then they can consider older agents, which may be applied to the case of strategic execution that takes care of consumer concerns. Additionally, if a firm aims to reinforce environmental management, then shareholders can select new CEOs because longer-tenured CEOs can become more banal for the execution of environmental CSR. Conversely, shareholders can maintain their current agents if they do not want to allot their resources to the environmental CSR domain. Next, the results also inform organizations that granting more stock options to CEOs leads these organizations to pursue more profitable and riskier projects rather than environmental CSR. Furthermore, airline shareholders may use the information that CEO duality brings about firms to take more risks instead of initiating CSR execution. That is, if airline principals aim to make airline business conditions safer, then they need to reduce the power of their agents. The findings 
of this study can also be adopted by airline managers to anticipate their competitors' CSR execution given the observable characteristics (e.g., age, tenure, stock option, and duality) of CEOs. Plus, the results of current work could be used to control top managers in the domain of CSR execution because CSR execution of CEOs could be negligible. Thus, principals can make their organization more ethical by hiring their agent as the directions to execute more CSR. In detail, shareholders can minimize the negative impact of CSR execution by hiring older and shorter-tenured CEOs, reducing stock option, and refraining duality. Additionally, the CSR decision could be reflected by the shareholder request because it could cause either business insurance or inefficient resource dedication to make a profit. Finally, the results can offer information for potential investors regarding the magnitude of organizational risk, in that higher debt financing lowers employee CSR; the stock of low-cost carriers may be more stable because these businesses tend to implement CSR more in the area of employee CSR and product CSR.

This study has some limitations. First, the study period was limited to 2016 because of the availability of CSR data. If future studies report the results using more updated information, then it will make the research on CSR and top management more fruitful. Moreover, future studies may need to consider more diverse CEO psychological characteristics to account for CEO narcissism and hubris for the CSR execution of airlines. Moreover, this research sample was constrained to US-based airlines; thus, scholars should consider airlines from various countries, which can not only increase the sample size but also can attain more reliable statistical inference. Additionally, future research might be able to consider environment, society, and governance (ESG) framework in the domain of airlines for future research because ESG is regarded as an essential area in business to accomplish sustainability.

Author Contributions: Data curation, investigation, supervision, L.J; formal analysis, draft writing, J.M. All authors have read and agreed to the published version of the manuscript.

Funding: This research received no external funding.

Data Availability Statement: Not applicable.

Conflicts of Interest: The authors declare no conflict of interest.

\section{References}

1. Cowper-Smith, A.; de Grosbois, D. The adoption of corporate social responsibility practices in the airline industry. J. Sustain. Tour. 2011, 19, 59-77. [CrossRef]

2. Karaman, A.S.; Akman, E. Taking-off corporate social responsibility programs: An AHP application in airline industry. J. Air Transp. Manag. 2018, 68, 187-197. [CrossRef]

3. Phillips, S.; Thai, V.V.; Halim, Z. Airline value chain capabilities and CSR performance: The connection between CSR leadership and CSR culture with CSR performance, customer satisfaction and financial performance. Asian J. Shipp. Logist. 2019, 35, 30-40. [CrossRef]

4. Abbas, J.; Mubeen, R.; Iorember, P.T.; Raza, S.; Mamirkulova, G. Exploring the impact of COVID-19 on tourism: Transformational potential and implications for a sustainable recovery of the travel and leisure industry. Curr. Res. Behav. Sci. 2021, 2, 100033. [CrossRef]

5. Azizi, M.R.; Atlasi, R.; Ziapour, A.; Abbas, J.; Naemi, R. Innovative human resource management strategies during the COVID-19 pandemic: A systematic narrative review approach. Heliyon 2021, 7, e07233. [CrossRef]

6. Cheng, Y.; Shen, H. United Airlines crisis from the stakeholder perspective: Exploring customers' ethical judgment, trust and distrust, and behavioral intentions. Public Relat. Rev. 2020, 46, 101908. [CrossRef]

7. Varma, T.M. Responsible leadership and reputation management during a crisis: The cases of Delta and United Airlines. J. Bus. Ethics 2020, 1-17. [CrossRef]

8. Freeman, R.E.; Wicks, A.C.; Parmar, B. Stakeholder theory and "the corporate objective revisited". Organ. Sci. 2004, 15, 364-369. [CrossRef]

9. Inoue, Y.; Lee, S. Effects of different dimensions of corporate social responsibility on corporate financial performance in tourismrelated industries. Tour. Manag. 2011, 32, 790-804. [CrossRef]

10. Hwang, J.; Choi, J.K. An investigation of passengers' psychological benefits from green brands in an environmentally friendly airline context: The moderating role of gender. Sustainability 2018, 10, 80. [CrossRef] 
11. Kim, Y.; Lee, S.; Roh, T. Taking another look at airline CSR: How required CSR and desired CSR affect customer loyalty in the airline industry. Sustainability 2020, 12, 4281. [CrossRef]

12. Hambrick, D.C.; Mason, P.A. Upper echelons: The organization as a reflection of its top managers. Acad. Manag. Rev. 1984, 9 , 193-206. [CrossRef]

13. Serfling, M.A. CEO age and the riskiness of corporate policies. J. Corp. Financ. 2014, 25, 251-273. [CrossRef]

14. Andreou, P.C.; Louca, C.; Petrou, A.P. CEO age and stock price crash risk. Rev. Financ. 2017, 21, 1287-1325. [CrossRef]

15. Chen, H.L. CEO tenure, independent directors and corporate innovation. J. Appl. Financ. Bank. 2013, 3, 187.

16. Luo, X.; Kanuri, V.K.; Andrews, M. How does CEO tenure matter? The mediating role of firm-employee and firm-customer relationships. Strateg. Manag. J. 2014, 35, 492-511. [CrossRef]

17. Kuo, H.C.; Wang, L.H.; Yeh, L.J. The role of education of directors in influencing firm R\&D investment. Asia Pac. Manag. Rev. 2018, 23, 108-120.

18. Li, J.; Tang, Y.I. CEO hubris and firm risk taking in China: The moderating role of managerial discretion. Acad. Manag. J. 2010, 53, 45-68. [CrossRef]

19. Li, F.; Li, T.; Minor, D. CEO power, corporate social responsibility, and firm value: A test of agency theory. Int. J. Manag. Financ. 2016, 12, 611-628. [CrossRef]

20. Velte, P. Does CEO power moderate the link between ESG performance and financial performance? A focus on the German two-tier system. Manag. Res. Rev. 2019, 43, 497-520. [CrossRef]

21. Zhu, D.; Chen, G. Narcissism, director selection, and risk-taking spending. Strateg. Manag. J. 2015, 36, 2075-2098. [CrossRef]

22. Sheikh, S. CEO power and corporate risk: The impact of market competition and corporate governance. Corp. Gov. Int. Rev. 2019, 27, 358-377. [CrossRef]

23. Altunbaş, Y.; Thornton, J.; Uymaz, Y. The effect of CEO power on bank risk: Do boards and institutional investors matter? Financ. Res. Lett. 2020, 33, 101202. [CrossRef]

24. Lie, E. On the timing of CEO stock option awards. Manag. Sci. 2005, 51, 802-812. [CrossRef]

25. Rajgopal, S.; Shevlin, T. Empirical evidence on the relation between stock option compensation and risk taking. J. Account. Econ. 2002, 33, 145-171. [CrossRef]

26. Sanders, W.G.; Hambrick, D.C. Swinging for the fences: The effects of CEO stock options on company risk taking and performance. Acad. Manag. J. 2007, 50, 1055-1078. [CrossRef]

27. Lee, W.S.; Moon, J. Determinants of CEO strategic risk-taking in the airline industry. Tour. Manag. Perspect. 2016, 18, 111-117. [CrossRef]

28. Donaldson, T.; Preston, L.E. The stakeholder theory of the corporation: Concepts, evidence, and implications. Acad. Manag. Rev. 1995, 20, 65-91. [CrossRef]

29. Friedman, A.L.; Miles, S. Developing stakeholder theory. J. Manag. Stud. 2002, 39, 1-21. [CrossRef]

30. Gibson, K. The moral basis of stakeholder theory. J. Bus. Ethics 2000, 26, 245-257. [CrossRef]

31. Jones, T.; Harrison, J.; Felps, W. How applying instrumental stakeholder theory can provide sustainable competitive advantage. Acad. Manag. Rev. 2018, 43, 371-391. [CrossRef]

32. Argandoña, A. The stakeholder theory and the common good. J. Bus. Ethics 1998, 17, 1093-1102. [CrossRef]

33. Laplume, A.; Sonpar, K.; Litz, R. Stakeholder theory: Reviewing a theory that moves us. J. Manag. 2008, 34, 1152-1189. [CrossRef]

34. Mamirkulova, G.; Mi, J.; Abbas, J.; Mahmood, S.; Mubeen, R.; Ziapour, A. New Silk Road infrastructure opportunities in developing tourism environment for residents better quality of life. Glob. Ecol. Conserv. 2020, 24, e01194. [CrossRef]

35. Kuo, T.; Kremer, G.; Phuong, N.; Hsu, C. Motivations and barriers for corporate social responsibility reporting: Evidence from the airline industry. J. Air Transp. Manag. 2016, 57, 184-195. [CrossRef]

36. Theodoulidis, B.; Diaz, D.; Crotto, F.; Rancati, E. Exploring corporate social responsibility and financial performance through stakeholder theory in the tourism industries. Tour. Manag. 2017, 62, 173-188. [CrossRef]

37. Werther, W.B., Jr.; Chandler, D. Strategic corporate social responsibility as global brand insurance. Bus. Horiz. 2005, 48, 317-324. [CrossRef]

38. Minor, D.; Morgan, J. CSR as reputation insurance: Primum non nocere. Calif. Manag. Rev. 2011, 53, 40-59. [CrossRef]

39. Brown, J.A.; Forster, W.R. CSR and stakeholder theory: A tale of Adam Smith. J. Bus. Ethics 2013, 112, 301-312. [CrossRef]

40. Godfrey, P.C.; Hatch, N.W.; Hansen, J.M. Toward a general theory of CSRs: The roles of beneficence, profitability, insurance, and industry heterogeneity. Bus. Soc. 2010, 49, 316-344. [CrossRef]

41. Wiig, A.; Kolstad, I. Multinational corporations and host country institutions: A case study of CSR activities in Angola. Int. Bus. Rev. 2010, 19, 178-190. [CrossRef]

42. Nakamura, E. Is corporate social responsibility in Japanese firms at the theoretically derived achievable level? An analysis of CSR inefficiency using a stochastic frontier model. Bus. Soc. Rev. 2016, 121, 271-295. [CrossRef]

43. Liu, L.; Tian, G.G. Mandatory CSR disclosure, monitoring and investment efficiency: Evidence from China. Account. Financ. 2019, 61, 595-644. [CrossRef]

44. Khan, F.R.; Westwood, R.; Boje, D.M. 'I feel like a foreign agent': NGOs and corporate social responsibility interventions into Third World child labor. Hum. Relat. 2010, 63, 1417-1438. [CrossRef]

45. Jacobs, B.; Singhal, V. Shareholder value effects of the Volkswagen emissions Scandal on the automotive ecosystem. Prod. Oper. Manag. 2020, 29, 2230-2251. [CrossRef] 
46. Cho, M.; Xiong, Y.; Boatwright, B. Through the lens of ethnicity: Semantic network and thematic analyses of United Airlines' dragging crisis. Public Relat. Rev. 2021, 47, 102006. [CrossRef]

47. Manner, M.H. The impact of CEO characteristics on corporate social performance. J. Bus. Ethics 2010, 93, 53-72. [CrossRef]

48. Hsu, W.; Chen, H.; Cheng, C. Internationalization and firm performance of SMEs: The moderating effects of CEO attributes. J. World Bus. 2013, 48,1-12. [CrossRef]

49. Yim, S. The acquisitiveness of youth: CEO age and acquisition behavior. J. Financ. Econ. 2013, 108, 250-273. [CrossRef]

50. Kraiczy, N.D.; Hack, A.; Kellermanns, F.W. CEO innovation orientation and R\&D intensity in small and medium-sized firms: The moderating role of firm growth. J. Bus. Econ. 2015, 85, 851-872.

51. Kim, B.; Lee, S.; Kang, K.H. The moderating role of CEO narcissism on the relationship between uncertainty avoidance and CSR. Tour. Manag. 2018, 67, 203-213. [CrossRef]

52. Javeed, S.A.; Lefen, L. An analysis of corporate social responsibility and firm performance with moderating effects of CEO power and ownership structure: A case study of the manufacturing sector of Pakistan. Sustainability 2019, 11, 248. [CrossRef]

53. Toppinen, A.; Hänninen, V.; Lähtinen, K. ISO 26000 in the assessment of CSR communication quality: CEO letters and social media in the global pulp and paper industry. Soc. Responsib. J. 2015, 11, 702-715. [CrossRef]

54. Jizi, M.I.; Salama, A.; Dixon, R.; Stratling, R. Corporate governance and corporate social responsibility disclosure: Evidence from the US banking sector. J. Bus. Ethics 2014, 125, 601-615. [CrossRef]

55. Jamali, D.; Hallal, M.; Abdallah, H. Corporate governance and corporate social responsibility: Evidence from the healthcare sector. Corp. Gov. Int. J. Bus. Soc. 2010, 10, 590-602. [CrossRef]

56. Davila, A.; Venkatachalam, M. The relevance of non-financial performance measures for CEO compensation: Evidence from the airline industry. Rev. Account. Stud. 2004, 9, 443-464. [CrossRef]

57. Ting, I.; Azizan, N.; Kweh, Q.L. Upper echelon theory revisited: The relationship between CEO personal characteristics and financial leverage decision. Procedia-Soc. Behav. Sci. 2015, 195, 686-694. [CrossRef]

58. Hambrick, D.C. Upper echelons theory: An update. Acad. Manag. Rev. 2007, 32, 334343. [CrossRef]

59. Jian, M.; Lee, K.W. CEO compensation and corporate social responsibility. J. Multinatl. Financ. Manag. 2015, 29, 46-65. [CrossRef]

60. Hsu, W.T.; Chen, H.L.; Ho, M. CEO Tenure and R\&D investment: Founders vs. agents and the Role of independent directors. Technol. Anal. Strateg. Manag. 2020, 32, 1209-1222.

61. Farag, H.; Mallin, C. The influence of CEO demographic characteristics on corporate risk-taking: Evidence from Chinese IPOs. Eur. J. Financ. 2018, 24, 1528-1551. [CrossRef]

62. McCarthy, S.; Oliver, B.; Song, S. Corporate social responsibility and CEO confidence. J. Bank. Financ. 2017, 75, 280-291. [CrossRef]

63. Karim, K.; Lee, E.; Suh, S. Corporate social responsibility and CEO compensation structure. Adv. Account. 2018, 40, 27-41. [CrossRef]

64. Lee, W.S.; Kim, I.; Moon, J. Determinants of restaurant internationalization: An upper echelons theory perspective. Int. J. Contemp. Hosp. Manag. 2016, 28, 2864-2887. [CrossRef]

65. Hou, W.; Lovett, S.; Rasheed, A. Stock option pay versus restricted stock: A comparative analysis of their impact on managerial risk-taking and performance extremeness. Strateg. Organ. 2020, 18, 301-329. [CrossRef]

66. Abbas, J.; Raza, S.; Nurunnabi, M.; Minai, M.S.; Bano, S. The impact of entrepreneurial business networks on firms' performance through a mediating role of dynamic capabilities. Sustainability 2019, 11, 3006. [CrossRef]

67. Muttakin, M.; Khan, A.; Mihret, D. The effect of board capital and CEO power on corporate social responsibility disclosures. J. Bus. Ethics 2018, 150, 41-56. [CrossRef]

68. Lewellyn, K.; Muller-Kahle, M. CEO power and risk taking: Evidence from the subprime lending industry. Corp. Gov. Int. Rev. 2012, 20, 289-307. [CrossRef]

69. Ozdemir, O.; Erkmen, E.; Binesh, F. Board diversity and firm risk-taking in the tourism sector: Moderating effects of board independence, CEO duality, and free cash flows. Tour. Econ. 2021. [CrossRef]

70. Gujarati, D.; Porter, D. Basic Econometrics; McGraw-Hill International Edition: New York City, NY, USA, 2009.

71. Wooldridge, J. Introductory Econometrics: A Modern Approach; South Western, Cengage Learning: Boston, MA, USA, 2009.

72. Baltagi, B. Econometric Analysis of Panel Data; John Wiley \& Sons: Hoboken, NJ, USA, 2008; Volume 1.

73. Harper, J.; Sun, L. CEO power and corporate social responsibility. Am. J. Bus. 2019, 34, 93-115. [CrossRef]

74. Grougiou, V.; Dedoulis, E.; Leventis, S. Corporate social responsibility reporting and organizational stigma: The case of "sin" industries. J. Bus. Res. 2016, 69, 905-914. [CrossRef]

75. Jenkins, H.; Yakovleva, N. Corporate social responsibility in the mining industry: Exploring trends in social and environmental disclosure. J. Clean. Prod. 2006, 14, 271-284. [CrossRef]

76. Petrovic-Lazarevic, S. The development of corporate social responsibility in the Australian construction industry. Constr. Manag. Econ. 2008, 26, 93-101. [CrossRef]

77. Scholtens, B. Corporate social responsibility in the international banking industry. J. Bus. Ethics 2009, 86, 159-175. [CrossRef]

78. Vaaland, T.I.; Heide, M. Managing corporate social responsibility: Lessons from the oil industry. Corp. Commun. Int. J. 2008, 13, 212-225. [CrossRef]

79. Walker, M.; Kent, A. Do fans care? Assessing the influence of corporate social responsibility on consumer attitudes in the sport industry. J. Sport Manag. 2009, 23, 743-769. [CrossRef] 